DOI: https://doi.org/10.24127/ajpm.v9i1.2654

\title{
MUNCULNYA KESADARAN METAKOGNISI DALAM MENYELESAIKAN MASALAH MATEMATIKA
}

\author{
Sukiyanto \\ STIT Al-Fattah Siman Lamongan, Indonesia \\ E-mail: $\quad$ sukiyanto@stitaf.ac.id
}

Received 22 January 2020; Received in revised form 19 February 2020; Accepted 28 March 2020

\begin{abstract}
Abstrak
Tujuan dalam penelitian ini adalah untuk mengetahui munculnya kesadaran metakognisi siswa dalam memecahkan masalah matematika. Metode dalam penelitian ini menggunakan metode gabungan (kuantitaif dan kualitatif) dengan menggunakan analisis deskriptif. Subjek dalam penelitian ini yaitu siswa kelas X MIPA-I SMA Unggulan BPPT Al-Fattah Lamongan yang berjumlah 19 siswa. Penelitian ini menggunakan instrumen yang berupa tes penyelesaian masalah, kuesioner, dan wawancara. Dalam penelitian ini diperoleh hasil siswa dengan kategori berkemampuan tinggi berjumlah 9 siswa dengan persentase 47,36 \%, kategori kemampuan sedang berjumlah 7 siswa dengan persentase 36,84\% dan kemampuan rendah berjumlah 3 siswa dengan persentase 15,78\%. Hal ini bermakna bahwa aspek munculnya kesadaran metakognitif siswa memahami pokok permasalahan sebelum menyelesaikan masalah matematika, sehingga siswa memahami langkah selanjutnya yang akan dilakukan dalam menyelesaikan masalah matematika. Pada aspek regulasi siswa berusaha berpikir dua kali, saat terdapat jawaban yang kurang benar, dan akan membetulkannya dengan menggunakan strategi atau cara yang lain untuk menyelesaikan masalah matematika sampai menemukan jawaban benar. Sedangkan pada aspek evaluasi, bahwa siswa mengetahui kemampuan yang dimilikinya dalam menyelesaikan soal.
\end{abstract}

Kata kunci: Kesadaran metakognisi; menyelesaikan masalah.

\begin{abstract}
The purpose of this study was to determine the emergence of an awareness of students' metacognition in solving mathematical problems. The method in this study uses a combined approach (quantitative and qualitative) using descriptive analysis. The subjects in this study were the students of class X MIPA-I High School BPPT Al-Fattah Lamongan with 19 students. This study uses instruments in the form of problem-solving tests, questionnaires, and interviews. In this study, the results obtained by students with high ability categories amounted to 9 students with a percentage of $47.36 \%$, the type of moderate abilities amounted to 7 students with a rate of $36.84 \%$, and low capacity amounted to 3 students with a percentage of $15.78 \%$. This means that aspects of the emergence of metacognitive awareness of students understand the subject matter before solving mathematical problems. Hence, students follow the next steps that will be taken in solving mathematical problems. In the regulatory aspect, students try to think twice, when there is an incorrect answer and will correct it using a strategy or another way to solve mathematical problems until they find the correct answer. Whereas in the aspect of evaluation, students know the ability they have in solving problems.
\end{abstract}

Keywords: Metacognitive awareness; problem solving.

\section{PENDAHULUAN}

Tujuan pendidikan matematika adalah mengaktualisasikan belajar siswa pada tingkat yang tertinggi (Ciltas \& Tatar, 2011). Metakognisi dalam pemecahan masalah dapat membantu siswa menyadari keberadaan masalah yang perlu dipecahkan, melihat seperti apa masalah yang sebenarnya, dan mengerti bagaimana untuk bisa mencapai tujuan atau solusi dari masalah tersebut (Kuzle, 2013). Menurut Nizlel dkk, (2018) bahwa ada tiga aktivitas metakognitif yang terlibat ketika siswa menyelesaikan masalah matematika, yaitu kesadaran 
metakognitif, regulasi metakognitif, dan evaluasi metakognitif. Kesadaran metakognitif didefinisikan sebagai kemampuan dalam melakukan refleksi, memahami, dan mengontrol pembelajaran. Kesadaran metakognitif berkaitan dengan kesadaran individu akan proses menyelesaikan masalah, pengetahuan khusus tentang masalah yang dihadapi, dan pengetahuan tentang strategi untuk menyelesaikan masalah. Kesadaran metakognitif juga mencakup pengetahuan tentang apa yang perlu dilakukan, apa yang telah dilakukan, dan apa yang mungkin dilakukan dalam proses menyelesaikan masalah matematika (Danang, 2017).

Penelitian tentang kesadaran metakognisi siswa dalam menyelesaikan masalah matematika dilakukan oleh beberapa peneliti, termasuk (Sengul \& Yasemin, 2012) hasil penelitiannya menunjukan bahwa ada hubungan yang signifikan antara menyelesaikan masalah dan keterampilan metakognitif. Ahmad, dkk, (2018) hasil penelitiannya bahwa kemampuan metakognitif siswa secara umum tidak berkembang secara optimal karena ruang lingkup materi yang terbatas, pengajaran strategi kognitif yang digunakan guru secara verbal saat memberikan pemahaman dan menyelesaikan masalah. Sedangkan menurut (Kusumaningtyas, 2018) menyatakan bahwa metakognisi muncul pada subjek saat pertemuan ke tujuh, sehingga dengan kemampuannya tersebut mereka sendiri mampu menyelesaikan masalah matematika. Dari beberapa penelitian tersebut belum ada yang meneliti tentang kesadaran metakognisi dalam menyelesaikan masalah.

$\begin{array}{lr}\text { Kenyataannya bahwa rata-rata } \\ \text { siswa mengalami } & \text { kesulitan } \\ \text { menyelesaikan masalah } & \text { dalam }\end{array}$

mempelajari ilmu matematika. Hasil observasi yang diperoleh menunjukkan bahwa beberapa peserta didik memandang matematika sebagai hal yang menarik dan sebagian lagi memandang bahwa matematika adalah hal yang membosankan. Permasalahan yang ditemukan tersebut disebabkan karena siswa sangat sulit memahami konsep dalam pelajaran Matematika. Menurut Jordan \& Levine (2009) berpendapat bahwa sebagian besar anak dengan kesulitan matematika ditandai dengan kelemahan dalam mengartikan simbol angka sekunder yang terkait pada bilangan cacah, relasi bilangan, dan luas yang tidak teratur yang dipengaruhi oleh pengalaman. Menurut Siregar \& Mara (2016), pengetahuan konseptual merupakan pengetahuan yang menunjukkan saling keterkaitan antara unsur-unsur dasar dalam struktur yang lebih besar dan semuanya berfungsi bersama-sama.

Saat siswa menyelesaikan masalah harus melibatkan proses kognitif dan metakognitif, karena siswa harus mampu menentukan strategi yang akan digunakan dan menyiapkan strategi alternatif jika dalam proses menyelesaikan masalah mengalami kesulitan atau terjadi perubahan situasi (Yirdirim \& Ersozlu, 2013). Maka dibutuhkan sebuah ranah pengetahuan pada tingkat sekolah menengah atas meliputi pengetahuan faktual, konseptual, prosedural, dan metakognitif (Kemdikbud, 2013). Standar pengetahuan metakognitif dijadikan standar kelulusan bagi peserta didik SMA dengan harapan mampu meningkatkan kemampuan berpikir peserta didik. Metakognitif menjadi salah satu parameter yang harus dicapai peserta didik tingkat menengah atas pada kurikulum 2013. Parameter metakognitif dianggap penting karena 
pengetahuan metakognitif menunjang keberhasilan pembelajaran peserta didik. Metakognitif akan mendorong kemampuan peserta didik dalam menyelesaikan masalah dan pengembangan keterampilan berpikir lebih tinggi (Purnamawati, 2013)

Berdasarkan hal tersebut, maka tujuan dari penelitian ini adalah untuk mengetahui munculnya kesadaran metakognisi siswa dalam memecahkan masalah matematika.

\section{METODE PENELITIAN}

Metode yang digunakan dalam penelitian ini adalah kuantitaif dan kualitatif dengan analisis deskriptif. Subjek dalam penelitian ini yaitu siswa kelas X MIPA-I SMA Unggulan BPPT Al-Fattah Lamongan yang berjumlah 21 siswa. Untuk memperoleh data dilakukan enam langkah yaitu sebagai berikut:

Pertama, siswa diberikan sebuah masalah berupa tes soal matematika kepada siswa kelas X MIPA-1 yang berjumlah 19 siswa dengan tujuan untuk memperoleh data kemampuan siswa dalam memecahkan masalah matematika.

Kedua, setelah jawaban diperoleh selanjutnya data jawaban tersebut dikelompokkan kedalam tiga kategori: tinggi, sedang dan rendah. Menentukan ketiga kategori tersebut dapat disajikan dalam Tabel 1.

Tabel 1. Kriteria kemampuan siswa dalam menyelesaikan masalah.

\begin{tabular}{cc}
\hline Nilai & Kriteria \\
\hline $68 \% \leq$ nilai $\leq 100 \%$ & Tinggi \\
$33 \% \leq$ nilai $<68 \%$ & Sedang \\
$<33 \%$ & Rendah \\
\hline
\end{tabular}

Ketiga, memberikan sebuah kuesioner yang terdiri dari 15 pernyataan dalam aktivitas metakognisi, yaitu: kesadaran, regulasi dan evaluasi yang memiliki indikator masingmasing.

$\begin{array}{ccr}\text { Keempat, } & \text { hasil kuesioner } \\ \text { sebagai evaluasi selama proses }\end{array}$ menyelesaikan masalah, Penilaian kesadaran metakognitif siswa diubah menjadi skor, dengan menggunakan skala likert, selanjutnya skor total dan rata-rata skor total dihitung untuk setiap item dalam aspek indikator metakognitif. Skor total rata-rata setiap item dihitung dengan menggunakan rumus:

$$
\text { Nilai : } \sum \frac{\text { skor yang diperoleh }}{\text { skor total }} \times 100
$$

Kelima, penyajian data dari hasil kuesioner berdasarkan kesadaran, regulasi, dan evaluasi metakognisi. Dikelompokkan berdasarkan aspekaspek metakognisi dan diklasifikasikan pada kategori tingkat kemampuan yang terdiri dari sangat baik, baik, dan cukup baik.

Setelah data diperoleh, dilakukan sebuah analisis dan dilengkapi hasil wawancara untuk menyempurnakan hasil, dengan tujuan untuk mengeksplorasi dan mengungkap munculnya kesadaran metakognisi dalam tiga indikator dalam aktivitas metakognisi, yaitu kesadaran, regulasi, dan evaluasi.

\section{HASIL DAN PEMBAHASAN}

Tahapan pertama yang dilakukan dalam proses penelitian yaitu memberikan tes kemampuan menyelesaikan masalah yang bertujuan untuk mengetahui kemampuan siswa, kemudian meninjau kembali hasil lembar kerja siswa pada tiap item soal yang telah diberikan. Tahap kedua memberikan kuesioner, dan selanjutnya dilakukan wawancara dengan siswa secara individu dengan memberikan 
DOI: https://doi.org/10.24127/ajpm.v9i1.2654

beberapa pertanyaan yang terkait dengan aktivitas metakognisi yaitu kesadaran, evaluasi, dan regulasi dengan tujuan untuk mengetahui proses kemampuan siswa dalam menyelesaikan masalah matematika. Ketiga tahapan tersebut adalah untuk memperoleh data kualitatif.

Hasil nilai kemampuan siswa dalam memecahkan masalah, kemudian dikelompokkan kedalam tiga kriteria, yaitu: tinggi, sedang dan rendah yang akan dijelaskan pada Tabel 2.

Tabel 2. Jumlah dan persentase kemampuan siswa dalam menyelesaikan masalah.

\begin{tabular}{ccc}
\hline Kriteria & Jumlah & Persentase (\%) \\
\hline Tinggi & 9 & $47,36 \%$ \\
Sedang & 7 & $36,84 \%$ \\
Rendah & 3 & $15,78 \%$ \\
\hline Total & $\mathbf{1 9}$ & $\mathbf{1 0 0 \%}$ \\
\hline
\end{tabular}

Berdasarkan data pada Tabel 2 diperoleh hasil bahwa siswa memiliki kemampuan yang tinggi dalam menyelesaikan masalah.

Analisis jawaban siswa dalam menyelesaikan masalah nomor 1
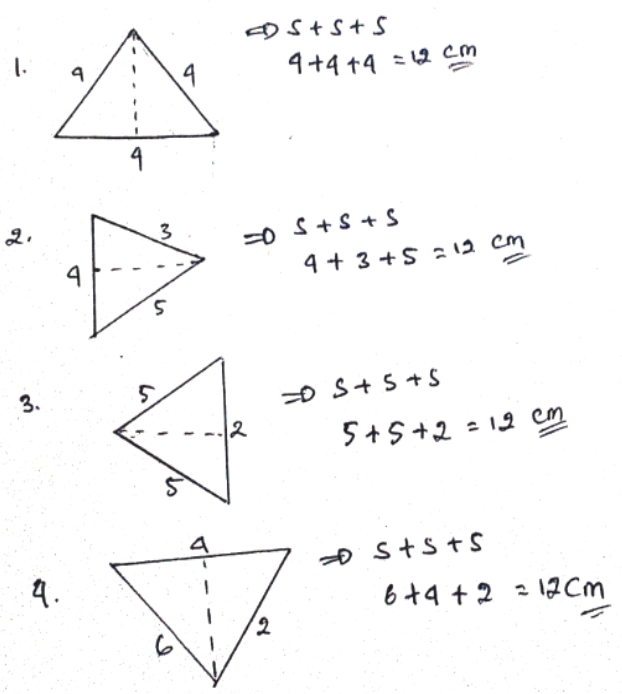

Gambar 1. Jawaban siswa dalam menyelesaikan masalah nomor 1 .
Pada soal nomor 1 terlihat bahwa siswa tidak mengalami kesulitan dalam menentukan masing-masing sisi pada segitiga. Berdasarkan hasil tes tulis siswa terlihat bahwa siswa bisa menggambarkan empat segitiga yang berbeda jenisnya serta menentukan setiap sisi pada segitiga dengan keliling yang sudah diketahui dan menggunakan rumus keliling dengan tepat. Akan tetapi siswa menggambar segitiga tidak memperhatikan ukuran panjang garisnya, sehingga garis yang digunakan tidak sesuai. Misalkan pada gambar segitiga nomor 4 dan empat panjang garisnya $2 \mathrm{~cm}$ tetapi hampir sama dengan panjang garisnya $2 \mathrm{~cm}$ tetapi hampir sama dengan panjang garis $5 \mathrm{~cm}$.

Analisis jawaban siswa dalam menyelesaikan masalah nomor 2

$$
\begin{aligned}
& \text { Diket } L=120 \mathrm{~cm}^{2} \\
& \text { Dicari panjang dan Lebar? } \\
& \qquad \begin{aligned}
120 & \\
& =p \times l \\
& =20 \times 6 \\
& =120 \\
\text { Jadi parjangnya } & =20 \\
\text { 6barnya } & =6
\end{aligned}
\end{aligned}
$$

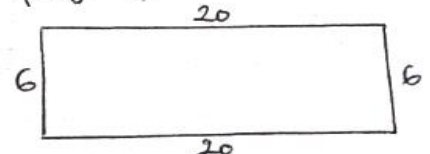

Gambar 2. Jawaban siswa dalam menyelesaikan masalah nomor 2 .

Pada soal nomor 2 terlihat siswa mampu menentukan panjang dan lebar pada persegi panjang dengan luas yang sudah diketahui dan menggunakan rumus dengan tepat. Akan tetapi siswa tidak menjelaskan proses dalam mencari panjang dan lebarnya.

Pada soal nomor 3 terlihat siswa mampu menentukan jumlah keramik yang dibutuhkan untuk menutupi lantai. Akan tetapi siswa belum dapat 
DOI: https://doi.org/10.24127/ajpm.v9i1.2654

mengambarkan keterkaitan masalah dengan konteks.

Analisis jawaban siswa dalam menyelesaikan masalah nomor 3 .

$$
\begin{aligned}
& \text { Paijjang sisi } 16 \mathrm{~m} \\
& \begin{aligned}
\text { ukuran } & 50 \mathrm{~cm} \times 50 \mathrm{~cm} \\
= & 25 \\
= & 25 \times 16 . \\
= & 400
\end{aligned}
\end{aligned}
$$

Gambar 3. Jawaban siswa dalam menyelesaikan masalah pada nomor 3

Analisis jawaban siswa dalam menyelesaikan masalah nomor 4

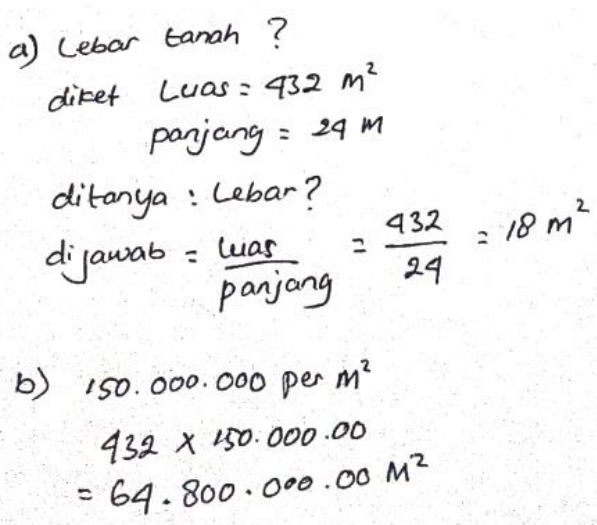

Gambar 4. Jawaban siswa dalam menyelesaikan masalah pada nomor 4 .

Pada soal nomor 4 siswa telah mampu menghitung lebar tanah yang dicari dan mengetahui harga tanah jika $R p 150.000,00 / \mathrm{m}^{2}$. Dan siswa sudah mampu memecahkan masalah dalam menghitung lebar tanah dan harga tanah.

Hasil kuesioner berdasarkan kesadaran, regulasi, dan evaluasi metakognisi

Pandangan siswa terhadap keterampilan metakognisi pada aspek kesadaran, regulasi, dan evaluasi dalam menyelesaikan masalah matematika. Dengan masing-masing aspek pernyataan, yang secara bersama-sama dapat mengungkap bagaimana kesadaran, regulasi, dan evaluasi yang dilakukan siswa dalam menyelesaikan masalah matematika.

\section{Analisis hasil kuesioner pada aspek kesadaran metakognisi}

Hasil yang telah diperoleh, dapat dikatakan bahwa aspek kesadaran dapat dikategorikan dalam interpretasi baik. Hal ini didukung dengan hasil wawancara terhadap siswa, setelah diberikan tes penyelesaian masalah. Bahwa siswa sebelum menyelesaikan masalah matematika, mereka memahami pokok permasalahan, sehingga siswa memahami langkah selanjutnya yang akan dilakukan dalam menyelesaikan masalah matematika.

\section{Analisis hasil kuesioner pada aspek regulasi metakognisi.}

Hasil yang telah diperoleh, pada aspek regulasi sama dengan pada aspek kesadaran yang dapat dikategorikan dalam interpretasi baik. Hal ini juga didukung dari hasil wawancara, bahwa siswa berusaha berpikir dua kali, saat terdapat jawaban yang kurang benar, mereka akan membetulkannya dengan menggunakan strategi atau cara yang lain untuk menyelesaikan masalah matematika sampai menemukan jawaban benar.

\section{Analisis hasil kuesioner pada aspek evaluasi metakognisi.}

Hasil yang telah diperoleh, pada aspek terakhir dari aktivitas metakognisi dalam menyelesaikan masalah yaitu aspek evaluasi yang tergolong dalam kategori baik. Ditinjau dari rata-rata bahwa siswa mengkaji ulang hasil pekerjaannya, dan memeriksa kembali hasil jawabannya untuk memastikan semuanya benar. Hal tersebut didukung dengan hasil wawancara yang telah 
dilakukan, bahwa siswa mengetahui kemampuan yang dimilikinya dalam menyelesaikan soal.

Analisis yang telah dijelaskan di atas, bahwa munculnya kesadaran metakognitif siswa pada kategori sangat baik, baik, dan cukup baik. Kategori sangat baik bahwa siswa mengetahui kemampuan dan pengetahuan yang dimilikinya dalam menyelesaikan masalah matematika. Kategori baik bahwa siswa menemukan kesulitan ketika memahami materi pelajaran, memperkirakan waktu yang dibutuhkan untuk menyelesaikan masalah, dan menyadari kemampuan yang mereka miliki. Kategori cukup baik, bahwa siswa membaca soal lebih dari satu kali.

Hal ini dapat diketahui bahwa metakognisi berperan penting dalam kegiatan menyelesaikan masalah. Hasil ini sejalan dengan penelitian Balk (2010); Sengul \& Yasemin (2012); Ahmad, dkk. (2018); Kusumaningtyas (2018) menunjukkan bahwa siswa yang sadar dengan metakognisinya dapat membantu meningkatkan keterampilan menyelesaikan masalah matematika. Hal yang sama juga dikemukakan oleh Anggo (2011) yang menyatakan bahwa metakognisi memainkan peran penting dalam mendukung kesuksesan siswa dalam menyelesaikan masalah.

Beberapa hasil penelitian tersebut, terdapat kesamaan bahwa munculnya kesadaran metakognitif terlihat adanya kaitan dengan menyelesaikan masalah yang dilakukan siswa. Siswa yang dapat memanfaatkan metakognisinya dengan baik, dapat menyelesaikan masalah matematika dengan baik. Sebaliknya, siswa yang tidak dapat memanfaatkan metakognisinya dengan baik, kurang dapat menyelesaikan masalah dengan baik.

\section{KESIMPULAN DAN SARAN}

Berdasarkan hasil penelitian, maka dapat disimpulkan pada aspek munculnya kesadaran metakognitif siswa memahami pokok permasalahan sebelum menyelesaikan masalah matematika, sehingga siswa memahami langkah selanjutnya yang akan dilakukan dalam menyelesaikan masalah matematika. Pada aspek regulasi siswa berusaha berpikir dua kali, saat terdapat jawaban yang kurang benar, dan akan membetulkannya dengan menggunakan strategi atau cara yang lain untuk menyelesaikan masalah matematika sampai menemukan jawaban benar. Sedangkan pada aspek evaluasi, bahwa siswa mengetahui kemampuan yang dimilikinya dalam menyelesaikan soal.

Penelitian ini dapat dijadikan alternatif pilihan guru dalam pembelajaran matematika sehari-hari, memunculkan kesadaran metakognisi dalam menyelesaikan masalah matematika.

\section{DAFTAR PUSTAKA}

Ahmad, H., Febryanti, Fatimah, \& Muthmainnah. (2018). Description of Student's Metacognitive Ability in Understanding and Solving Mathematics Problem. 4th International Conference on Operational Research (InteriOR). IOP Conf. Series: Materials Science and Engineering (pp.1-7)

Anggo, M. (2011). The Metacognitive Process of Teacher College Students in Solving Mathematical Problem. Proceeding International Seminar and the Fourth National Conference on Mathematics Education (pp.368-376). Yogyakarta: Universitas Negeri Yogyakarta. 
Balk, F. M. A. (2010). The Influence of Metacognitive Questions on The Learning Process during Mathematical Tasks in TeacherStudent Conversations : A Design Study. Master thesis from Utrecht University.

Ciltas, A., \& Tatar, E. (2011). Diagnosing learning difficulties related to the equation and inequality that contain terms with absolute value. International Online Journal of Educational Sciences, 3(2), 461-473.

Danang, S. (2017). Metacognition Process of Students Class X Senior High School in Mathematic Problem Solving. Journal of Research \& Method in Education (IOSR-JRME), 7(5),1-7.

Jordan, N.C., \& Levine, S,C. (2009). Socioeconomic Variation, Number Competence, and Mathematics Learning Difficulties in Young Children. Development disabilities research reviews, 15, 60-68.

Kemdikbud. (2013). Peraturan Menteri Pendidikan dan Kebudayaan No. 54 Tahun 2013 tentang Standar Kelulusan. Jakarta: Kemendikbud.

Kusumaningtyas, N. (2018). The Emergence of Students' Metacognition In The Process of Mathematical Problem Solving. International Journal of Insightfor Mathematics Teaching, 1(1), 6275.

Kuzle, A. (2013). Patterns of metacognitive during problem Solving in Dynamic Geometry Environment. International Electronic Journal of Mathematics Education, 1(8), 20-39.
Nizlel, H., Akbar, S., Subanji, \& Swasono, R. (2018). The errors of metacognitive evaluation on metacognitive failure of students in mathematical problem solving. IOP Conf. Series: Journal of Physics: Conf. Series 1008 (2018) 012073. doi :10.1088/17426596/1008/1/012073.

Purnamawati. (2013). Pengembangan Model Pembelajaran Bidang Keahlian Elektronika Industri Berbasis Metakognisi. Cakrawala Pendidikan, 32 (1), 41-53.

Sengul, S., \& Yasemin, K. (2012). Metacognitive aspects of solving function problems. Procedia Social and Behavioral Sciences (46) 2178-2182.

Sireger, E., \& Mara, B.H. (2016). Pengaruh Model Pembelajaran Kooperatif Tipe Group Investigation (GI) Terhadap Pengetahuan Konseptual Siswa SMA Muhammadiyah 2 Medan T.P. 2015/2016. Jurnal Inpafi, 4(4).

Yildirim, S., \& Ersozlu, Z. N. (2013). The relationship Between Students' Metacognitive Awareness and Similiar Types of Mathematical Problems. Eurasia Journal of Mathematics, Science \& Technology Education, 9(4), 411415. 